\title{
人工衛星内部の圧力*
}

\author{
猿 渡 英 樹*1
}

\section{Internal Pressure of a Satellite}

Hideki SARUWATARI*1

\begin{abstract}
${ }^{*}$ Environmental and Structural Test Laboratory, Office of Space Flight and Operations, Japan Aerospace Exploration Agency 2-1-1, Sengen, Tsukuba, Ibaraki 305-8505
\end{abstract}

(Received November 15, 2007, Accepted April 5, 2008)

\begin{abstract}
The operation of high voltage equipments inside a satellite may trigger electric discharge if the pressure around them is above the threshold. In a thermal vacuum test, high voltage equipments are turned on after the vacuum gage outside a satellite indicates a safe level - below the threshold - to avoid electrical discharge. However, since a satellite has quite a few outgassing sources in it, along with the limited conductance, the internal pressure is higher than the external pressure. So there is a possibility that the internal pressure is still above the threshold even after the external pressure has gone below it. To find out if it is safe to judge when to turn on high voltage equipments solely from the gage outside a satellite, we measured the pressure of both inside and outside a satellite, by placing a vacuum gage in both places. Measurement results showed that the internal pressure remained above the threshold even after the external pressure had fallen below it. As a consequence, it is confirmed that in a thermal vacuum test the power supplying point is better to be judged upon the internal pressure for the case of a satellite with high voltage equipments.
\end{abstract}

\section{1. はじめに}

人工衛星に搭載されている高電圧機器は, 機器周囲の圧力 が特定の範囲内にある状態での通電において放電を誘発する 可能性がある．放電防止のためには，機器の電極を充填材等 で覆うといった設計上の対策に加えて, 放電の可能性がある 圧力領域では機器の電源を投入しないといった運用上の考慮 も行われている．このような運用上の考慮は, ロケットで打 上げられた後の宇宙空間だけでなく, 地上試験においても注 意する必要がある.

人工衛星の地上試験の一つである熱真空試験においては, 試験設備（スペースチャンバ）に常設された真空計の值が放 電の可能性がある圧力領域を過ぎた後に機器の電源を投入す るという放電防止対策を実施している，ところで, 高電圧機 器が搭載される人工衛星内部には, 塗料, 接着剂, 配線被覆 等, 多量のガス放出源が存在する. また人工衛星内部と外部 の間のコンダクタンスは有限の值である.したがって, 定性 的には人工衛星内部は外部よりも圧力が高い. 熱真空試験に おける放電防止対策は, 人工衛星内部と外部の圧力差が無視 できる程小さい，という前提に立っている．その前提を確認 するために, 独宇宙航空研究開発機構 筑波宇宙センターの $8 \mathrm{~m} \phi$ スペースチャンバにおいて 2006 年 12 月に実施された地 球観測衛星の開発モデルの熱真空試験の際に, 人工衛星内部 と外部の圧力を測定した.

\section{2.＼cjkstart熱真空試験における放電防止の現状と問題点}

熱真空試験とは, 宇宙の極低温高真空を模擬した環境にお いて人工衛星の温度が決められた範囲内に維持され, 設計通 りの機能, 性能を発揮することを確認する試験である. ス ペースチャンバ内に人工衛星を入れて試験を行う. スペース

* 平成19年11月15日 第48回真空に関する連合講演会で発表

*1 独立行政法人 宇宙航空研究開発機構宇宙基幹システム本部試 験センター（干305-8505 茨城県つくば市千現 2-1-1)
チャンバ内部には, 宇宙の極低温状態を模擬するために液体 窒素で- $190^{\circ} \mathrm{C}$ 程度に冷却されたシュラウド（アルミフィン 管の集合体）が取り付けられている. またスペースチャンバ は, クライオソープションポンプ等により $10^{-5} \mathrm{~Pa}$ 程度に排 気される.

熱真空試験では1.33 Pa〜 $1.33 \times 10^{-3} \mathrm{~Pa}$ を放電危険領域と 定義し, 排気段階に打いてスペースチャンバ内圧力がこの領 域にある間は, 高電圧機器等の電源を投入しないようにして いる.

熱真空試験における圧力測定は，スペースチャンバに常設 されている真空計により行われている. 放電防止の対象であ る高電圧機器の多くは, 人工衛星の内部に取り付けられてい る. Fig. 1 に真空計の位置と高電圧機器の位置の関係を示

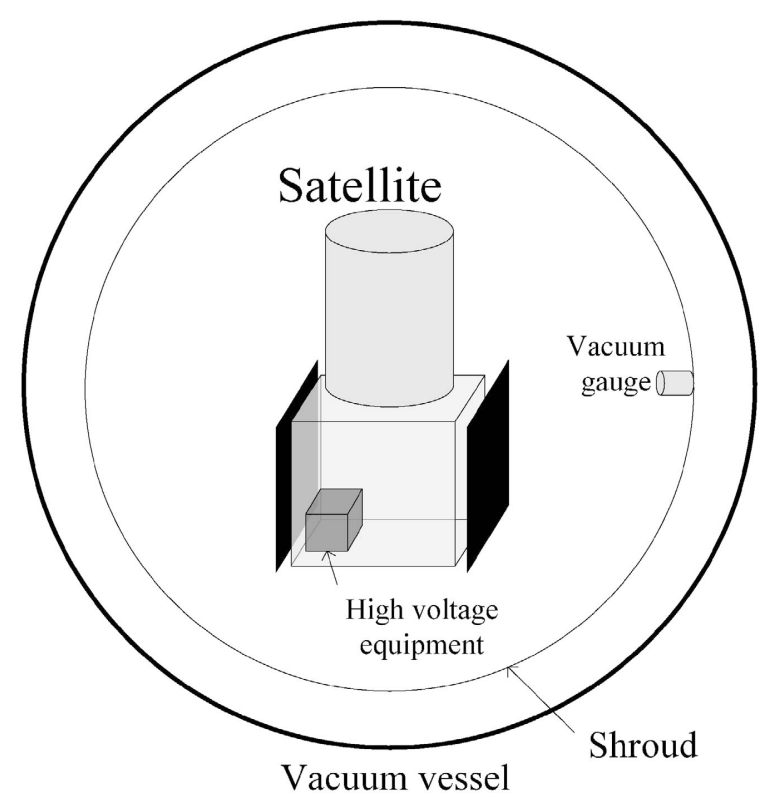

Fig. 1 Positions of high voltage equipment and vacuum gauge. 
す.

人工衛星内部からのガス放出量が多い場合や人工衛星の開 口面積が内容積に対して小さい場合には, スペースチャンバ 常設真空計周辺の圧力が放電危険領域より低くても, 高電圧 機器周辺の圧力は放電危険領域内である可能性がある.この 時に高電圧機器の電源を投入すると, 放電を誘発する危険が ある。

人工衛星内部からのガス放出量を正確に見積もることは難 しいため,このような危険性の有無を確認するためには, 人 工衛星内部の圧力を実測することが必要である.

\section{3. 圧力測定方法}

\section{1 測定対象}

測定対象の地球観測衛星は，ミッション部（観測センサお よび観測センサを搭載する部分）とバス部（観測センサの働 きをサポートする部分）から構成される.

バス部内部の表面にはウレタン系黒色塗料が塗装されてい る. 観測センサ内部の表面は黒色陽極酸化処理が施されてい る. 単位面積当たりのガス放出量は黒色塗料の方が陽極酸化 被膜よりも大きく, またバス部内部の表面積の方が観測セン サ内部の表面積よりも大きいことから，バス部内部における ガス放出量が, 観測センサ内部における放出量よりも多いこ とが予想された。

さらにバス部には目視で確認できる大きさの開口部は設け られていない。一方, 観測センサ光学部は地球観測のための 大面積の開口部を有しており, 外部とのコンダクタンスは比 較的大きい.

これらの理由から, バス部内部と人工衛星外部の圧力差 は, 観測センサ内部と人工衛星外部の圧力差よりも大きいこ とが予想された。

\section{2 使用した真空計}

人工衛星の平衡温度への影響を避けるため, 人工衛星内部 圧力の測定には低発熱量型の小型電離真空計（キャノンアネ ルバ製 MG-2I）を 4 式使用した. 人工衛星外部の圧力は， 8

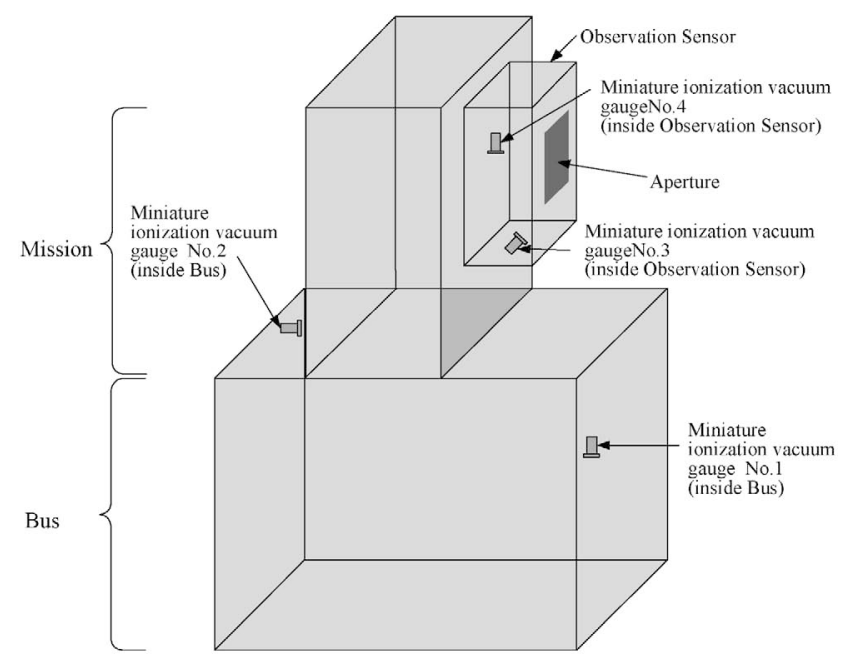

Fig. 2 Mounting positions of miniature ionization vacuum gauges. $\mathrm{m} \phi$ スペースチャンバ常設のヌード型電離真空計（キャノン アネルバ製 NIG-2F）を用いて測定した.

\section{3 真空計設置位置}

小型電離真空計 4 式のうち 2 式を観測センサ内部に, 残 り 2 式をバス部内部に設置した。真空計の設置位置を Fig. 2 に示す.

\section{4. 圧力測定結果および考察}

\section{1 圧力測定結果}

熱真空試験では, 排気開始の約 11 時間後に人工衛星内部 の機器の電源を ON した. また約 22 時間後に人工衛星外部 に設置した太陽光等からの熱入力を模擬するための赤外ヒー タパネルの電源を ON した. Fig. 3 に圧力測定結果を示 す. 排気開始から約 6 時間後, 観測センサ内部に設置した 小型電離真空計 3,4 および設備常設のヌード型電離真空計 の読み值は短時間で $10^{-3} \mathrm{~Pa}$ 以下に下がり, 放電危険領域か ら脱出した。 読み值が短時間で下がったのは, 液体窒素でー $190^{\circ} \mathrm{C}$ 程度に冷却されたシュラウドによりスペースチャンバ 内の残留気体の多数を占める水分子が排気されたためである.

一方，バス部内部に設置した小型電離真空計 1,2 の読み 值が下がる速度は遅く, 排気開始 12 時間後の時点において も約 $2 \times 10^{-2} \mathrm{~Pa}$ と放電危険領域内の值を示した. 同時期の 小型電離真空計 3,4 の読み值は約 $2 \times 10^{-4} \mathrm{~Pa}$, 設備常設真 空計の読久值は約 $5 \times 10^{-5} \mathrm{~Pa}$ であった。この時点では, バ ス部内部および観測センサ内部は, 外部に比較して400倍お よび 4 倍の圧力であり, 人工衛星内部と外部には有意な圧 力差があることが確認された.

排気開始から約20時間以降の小型電離真空計の読久值の 変化は, 設置箇所により大きく異なる. 小型電離真空計 3,4 の読み值は排気開始後約 22 時間の時点で上がっている. 同 時期に人工衛星外部の赤外ヒータパネルの電源が ONさ れ, 観測センサの温度が $20^{\circ} \mathrm{C}$ 程度上昇した。したがって観 測センサ内部からのガス放出量が増加したことが原因である と考えられる.

小型電離真空計 1,2 の読み值は低下し続けているが, 排 気開始後 24 時間経過した頃から, 小型電離真空計 1,2 の読 み值の差が大きくなっている. 小型電離真空計 1 の読み值 は小型電離真空計 2 よりも早く低下し, 排気開始後 42 時間 経過時点では小型電離真空計 3,4 よりも低くなった．この 頃から小型電離真空計 1,2 のフィラメント電流が OFF する ようになった. 特に小型電離真空計 1 においては, 再度フ ィラメント電流を ON してもすぐに OFFするようになった ため，排気開始後55時間で測定を終了した.

\section{2 小型電離真空計 1 の読み值低下の原因}

小型電離真空計 1 の読久值が真の圧力を示しているとす ると, 排気開始から 42 時間経過した時点で, バス部内部の 圧力は観測センサ内部よりも低くなったことになる.しかし ながら以下に述べる理由から, 実際にはこの時点においても バス部内部の圧力は観測センサ内部よりも高かったと考えら れる。

バス部内部の圧力は（バス部内部からのガス放出量）/(バ ス部内部と外部との間のコンダクタンス）である。バス部内 


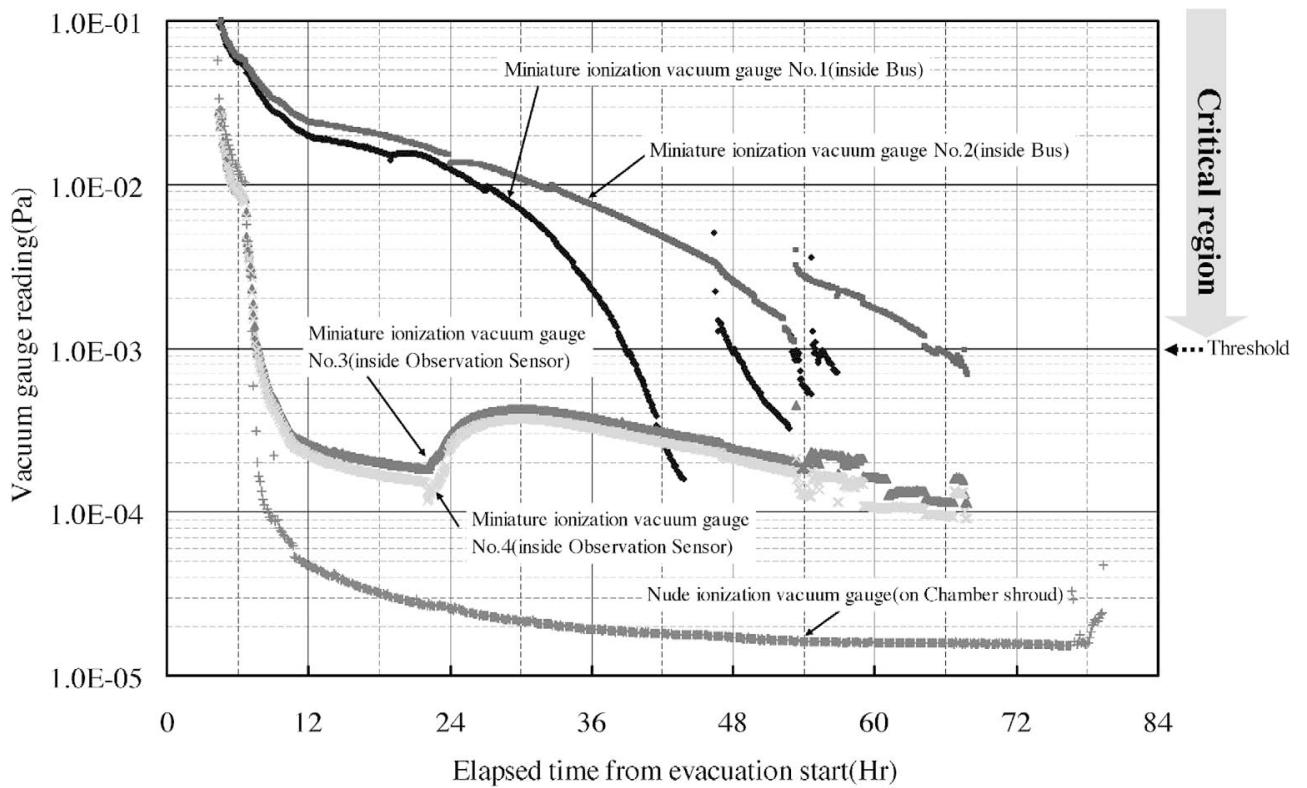

Fig. 3 Result of satellite internal pressure measurement.

部と外部との間のコンダクタンスは一定であるから, 圧力の 変化はガス放出量の変化に比例する。 人工衛星に使用する有 機材料からのガス放出量は, 時間のべき乗の逆数 $\mathrm{t}^{-1}$ に比例 して低下する1)ことが知られている. 小型電離真空計 1 の読 及値は排気開始後 30 時間から 42 時間の期間において $\mathrm{t}^{-10}$ に 比例して低下している. 小型電離真空計 1 の読及值が真の 圧力を示しているとすると, 真空計設置位置でのガス放出量 は $\mathrm{t}^{-10}$ に比例して低下したことになるが，そのような材料は 存在しない。そのため, 小型電離真空計 1 の読及值が低下 した理由はバス部内部の圧力低下ではなく，別に理由がある と考えられる。な扔ガス放出量は温度に依存するが，同時期 のバス部内部の温度は一定に保たれていたことを確認してい る.

バス部内部には塗料等から放出された分子が存在する．こ のような污染分子の多い環境で電離真空計を使用すると，污 染分子がコレクタに堆積して絶縁層を形成し，感度を低下さ せる2 (3) ことが知られている. 今回の測定においても同様の 理由により真空計の感度が低下し，小型電離真空計 1 の読 久值が低下した可能性がある。

この推定が正しいことを確認するために，電離真空計を電 子衝撃によりクリーニングし，その前後での読及值をエキス トラクタ真空計と比較した。その結果，コレクタを電子衝撃 クリーニングする前は, 小型電離真空計 1 の読及值はエキ ストラクタ真空計の読み值の 0.028 倍であったのに対し, ク リーニング後は 0.7 倍であった。 小型電離真空計 2 の場合 は，クリーニング前が 0.25 倍, クリーニング後が 0.81 倍であ った。したがって，今回の測定において排気開始後 24 時間
以降にバス部内部の真空計の読み值が低下したのは, バス部 内部表面から放出された分子が電離真空計のコレクタに付着 し，感度を低下させたことが原因と考えられる。

この推定が正しいとすると，バス部内部の圧力は排気開始 24 時間以降も $1 \times 10^{-2} \mathrm{~Pa}$ 程度の值であったと考えられる。 海外において人工衛星内部の圧力を測定した例4)において も, 人工衛星内部圧力は $1 \times 10^{-2} \sim 10^{-3} \mathrm{~Pa}$ 程度の值であ り, 今回の測定結果と矛盾しない。

\section{5. まと め}

人工衛星の開発モデルの熱真空試験において人工衛星内部 と外部の圧力を測定した結果，人工衛星内部と外部の圧力に 有意差があることを確認した。

内部に高電圧機器を搭載した人工衛星の熱真空試験では, 人工衛星内部の圧力を測定し，その結果に基づいて機器の電 源投入時期を判断することが望をれる.

人工衛星内部々外部の圧力差は，人工衛星毎に異なること が考えられるため，今後も機会をみて測定することとした い.な抢その際には，污染分子の多い環境に抢忊圧力測定 方法についての検討が必要である。

\section{〔文献〕}

1) John J. Scialdone: J. Spacecraft, 23 (1986) 373.

2) F. Watanabe: Vacuum, 47 (1996) 567.

3) J. R. Young: J. Vac. Sci. Technol., 10 (1973) 212.

4) H. E. Nuss and I. Streuff: Proc. 2nd Int. Symp.on Environmental Testing for Space Programmes, Noordwijk, The Netherlands, 1993, ESA WPP-066 231. 